ORIGINAL ARTICLE

\title{
Tumour characteristics and prognosis of breast cancer patients carrying the germline CHEK2 $2^{\star} 1100$ delC variant
}

\author{
G H de Bock*, M Schutte, E M M Krol-Warmerdam, C Seynaeve, J Blom, C T M Brekelmans, \\ H Meijers-Heijboer, C J van Asperen, C J Cornelisse, P Devilee, R A E M Tollenaart, J G M Klijn†
}

J Med Genet 2004;41:731-735. doi: 10.1136/jmg.2004.019737

See end of article for authors' affiliations

Correspondence to:

G H de Bock, Department

of Medical Decision

Making, Leiden University

Medical Center, PO Box

9600, 2300 RC Leiden,

The Netherlands;

g.h.de_bock@lumc.nl

Revised version received 28 June 2004

Accepted for publication

28 June 2004
Background: The germline CHEK2* $1100 \mathrm{delC}$ variant has been associated with breast cancer in multiple case families where involvement of BRCA 1 and BRCA2 has been excluded.

Methods: We have investigated the tumour characteristics and prognosis of carriers of this germline variant by means of a prospective cohort study in an unselected cohort of 1084 consecutive patients with primary breast cancer. Data were collected for 34 patients with a germline CHEK2*1100delC mutation and for 102 patients without this mutation, stratified by age and date of diagnosis of the first primary breast cancer (within 1 year).

Results: Carriers developed steroid receptor positive tumours (oestrogen receptor (ER): 91\%; progesterone receptor (PR): $81 \%$ ) more frequently than non-carriers (ER: 69\%; PR: 53\%; $p=0.04$ ). Mutation carriers more frequently had a female first or second degree relative with breast cancer $(p=0.03)$, or had any first or second degree relative with breast or ovarian cancer $(p=0.04)$. Patients with the CHEK2 variant had a more unfavourable prognosis regarding the occurrence of contralateral breast cancer (relative risk $(R R)=5.74 ; 95 \%$ confidence interval $(C I) 1.67$ to 19.65$)$, distant metastasis-free survival $(R R=2.81 ; 95 \%$ $\mathrm{Cl} 1.20$ to 6.58), and disease-free survival ( $\mathrm{RR}=3.86 ; 95 \% \mathrm{Cl} 1.91$ to 7.78$)$. As yet, no difference with respect to overall survival has been found at a median follow up of 3.8 years.

Conclusion: We conclude that carrying the CHEK2*1100delC mutation is an adverse prognostic indicator for breast cancer. If independently confirmed by others, intensive surveillance, and possibly preventive measures, should be considered for newly diagnosed breast cancer cases carrying the CHEK2*1100delC variant.
A bout $15 \%$ of all breast cancer patients have a positive family history for this disease. ${ }^{1}$ A polygenic model to explain this familial aggregation has been proposed, ${ }^{2}$ and several genes have been identified to date. Mutated alleles of BRCA1, BRCA2, and TP53 confer highly increased breast cancer risks, but each gene accounts for only a small fraction of the familial clustering and the total breast cancer incidence. ${ }^{3}{ }^{4}$ Other known genes, such as ATM, and unknown genes are believed to confer much lower breast cancer risks. ${ }^{56}$ However, as their mutated alleles are believed to be common in the general population, they may account for a substantial proportion of breast cancer cases. Recently, it has been found that a specific mutation in the CHEK2 gene, termed CHEK2* 1100 delC, is associated with breast cancer occurring in multiple-case families in which the involvement of BRCAl and BRCA2 has been excluded. ${ }^{7-9}$ CHEK2 is involved in cell cycle control and DNA repair through its ability to phosphorylate p53, Cdc25c, and BRCAl, ${ }^{10}$ a function which is abrogated by the 1100delC mutation. This mutation has a population frequency of approximately $1 \%$, and has been suggested to confer an approximately twofold elevated risk of breast cancer. ${ }^{78}$ In this study, we investigated the characteristics of $\mathrm{CHEK}^{*} 1100 \mathrm{delC}$ associated tumours, and the prognosis of patients with such breast cancers, in a prospectively collected cohort containing 1084 consecutive unselected patients with primary breast cancer.

\section{METHODS}

Patient population and study design

Patients were consecutively recruited irrespective of their family history from three centres in south west Netherlands (two academic cancer centres in Leiden and Rotterdam, and one general hospital in Leiden) between October 1, 1996 and July 1, 2002. Patients with a previous primary breast cancer were excluded from the study. There was no selection for age at diagnosis in the Leiden hospitals, while in the Rotterdam Cancer Centre there was an upper limit of 70 years of age. The median follow up time for the total group was 3.8 years (range 0.2-6.4 years; mean 3.6 years); for those without any event the median follow up time was 3.6 years (range $0.2-$ 5.7 years; mean 3.5 years).

We have investigated the tumour characteristics and prognosis of carriers of this germline variant by means of a prospective cohort study of these 1084 unselected consecutive patients with primary breast cancer. Because survival data were not directly available and had to be retrieved from clinical files, the tumour characteristics of the first primary breast cancer and the prognosis in $C H E K 2^{*} 1100$ delC carriers were compared with the characteristics of a stratified sample of non-carriers (three carrier patients per non-carrier patient). Non-carrier patients were stratified for age and date of diagnosis of the first primary breast cancer (within 1 year). Non-carriers were randomly selected from all noncarriers who were eligible for a particular carrier. The following were used as parameters for prognosis: diseasefree survival, incidence of contralateral breast tumours, localregional recurrences and distant metastases, and overall survival.

The Medical Ethical Review Boards of the involved centres approved the study protocol, under the condition that written informed consent was obtained from the patients.

Abbreviations: ER, oestrogen receptor; PR, progesterone receptor; RR, relative risk 


\section{Data collection and methods}

Clinical and pathology data (including oestrogen receptor (ER) and progesterone receptor (PR) status) of the patients were retrieved from medical files and pathology reports. Information on follow up (including second malignancies) was retrieved from the records of the CHEK2*1100delC

Table 1 Clinical-pathological characteristics of patients with $(n=34)$ and without $(n=102)$ a CHEK2* 1100 delC mutation at the time of diagnosis of the first primary breast cancer

\begin{tabular}{|c|c|c|c|}
\hline & $\begin{array}{l}\text { CHEK2 } \\
\text { mutation } \\
\text { present } \\
(n=34)\end{array}$ & $\begin{array}{l}\text { CHEK2 } \\
\text { mutation } \\
\text { absent } \\
(n=102)\end{array}$ & Diff. \\
\hline $\begin{array}{l}\text { Age (mean; SD; } \\
\text { range) }\end{array}$ & $\begin{array}{l}49.0 ; 11.6 ; \\
25-83\end{array}$ & $\begin{array}{l}48.4 ; 11.9 ; \\
23-86\end{array}$ & $\begin{array}{l}t=0.26 \\
p=0.80\end{array}$ \\
\hline \multicolumn{4}{|l|}{ Tumour size } \\
\hline $2 \mathrm{~cm}$ or less & $16(53 \%)$ & $49(53 \%)$ & \\
\hline More than $2 \mathrm{~cm}$ & $14(47 \%)$ & $43(47 \%)$ & $\chi^{2}=0.00$ \\
\hline Unknown & 4 & 10 & $p=0.99$ \\
\hline \multicolumn{4}{|l|}{ Axillary nodal status } \\
\hline Negative & $14(40 \%)$ & $43(44 \%)$ & \\
\hline Positive & $19(60 \%)$ & $53(56 \%)$ & $\chi^{2}=0.06$ \\
\hline Unknown & 1 & 6 & $p=0.81$ \\
\hline \multicolumn{4}{|l|}{ Tumour stage } \\
\hline DCIS & $2(7 \%)$ & $5(6 \%)$ & \\
\hline $1-11$ & $22(73 \%)$ & $74(87 \%)$ & \\
\hline III-IV & $6(20 \%)$ & $6(7 \%)$ & $\chi^{2}=4.08$ \\
\hline Unknown & 4 & 17 & $\mathrm{p}=0.13$ \\
\hline \multicolumn{4}{|l|}{ Histological tumour type } \\
\hline Ductal invasive & $25(73 \%)$ & $79(84 \%)$ & \\
\hline Lobular invasive & $4(12 \%)$ & $8(9 \%)$ & \\
\hline DCIS & $2(6 \%)$ & $5(5 \%)$ & \\
\hline Other & $3(9 \%)$ & $3(2 \%)$ & $\chi^{2}=3.50$ \\
\hline Unknown & - & 7 & $p=0.32$ \\
\hline \multicolumn{4}{|c|}{ Oestrogen receptor status } \\
\hline Negative & $2(9 \%)$ & $22(31 \%)$ & \\
\hline Positive & $21(91 \%)$ & $48(69 \%)$ & $\chi^{2}=4.67$ \\
\hline Unknown & 11 & 32 & $p=0.03$ \\
\hline \multicolumn{4}{|l|}{$\begin{array}{l}\text { Progesterone receptor } \\
\text { status }\end{array}$} \\
\hline Negative & $3(19 \%)$ & $25(47 \%)$ & \\
\hline Positive & $13(81 \%)$ & $27(53 \%)$ & $\chi^{2}=4.35$ \\
\hline Unknown & 19 & 50 & $p=0.04$ \\
\hline \multicolumn{4}{|l|}{ Grade† } \\
\hline Good (grade I) & $4(19 \%)$ & $12(15 \%)$ & \\
\hline Moderate (grade II) & $11(52 \%)$ & $34(44 \%)$ & \\
\hline Bad (grade III) & $6(29 \%)$ & $32(41 \%)$ & $\chi^{2}=1.09$ \\
\hline Unknown & 13 & 24 & $\mathrm{p}=0.58$ \\
\hline \multicolumn{4}{|l|}{ Surgical procedure } \\
\hline $\begin{array}{l}\text { Breast conserving } \\
\text { therapy }\end{array}$ & $17(52 \%)$ & $40(40 \%)$ & \\
\hline $\begin{array}{l}\text { Breast conserving } \\
\text { therapy with sentinel } \\
\text { node procedure }\end{array}$ & $1(3 \%)$ & $5(5 \%)$ & \\
\hline Mastectomy & $14(42 \%)$ & $50(49 \%)$ & \\
\hline $\begin{array}{l}\text { Mastectomy with } \\
\text { sentinel node } \\
\text { procedure }\end{array}$ & $1(3 \%)$ & $4(4 \%)$ & \\
\hline Other & - & $2(2 \%)$ & $\chi^{2}=2.01$ \\
\hline Unknown & 1 & 1 & $\mathrm{p}=0.74$ \\
\hline \multicolumn{4}{|l|}{ Resection line involved } \\
\hline No & 27 (87\%) & $81(88 \%)$ & \\
\hline Yes & $4(13 \%)$ & $11(12 \%)$ & $\chi^{2}=0.02$ \\
\hline Unknown & 3 & 10 & $\mathrm{p}=0.89$ \\
\hline \multicolumn{4}{|c|}{ Adjuvant systemic therapy } \\
\hline No & $13(40 \%)$ & $39(39 \%)$ & \\
\hline Chemotherapy & $9(27 \%)$ & $18(18 \%)$ & \\
\hline Endocrine therapy & $3(9 \%)$ & $13(13 \%)$ & \\
\hline Combination of both & $8(24 \%)$ & $30(30 \%)$ & $\chi^{2}=1.66$ \\
\hline Unknown & 1 & 2 & $p=0.65$ \\
\hline \multicolumn{4}{|l|}{ Adjuvant radiotherapy } \\
\hline No & $9(27 \%)$ & $29(29 \%)$ & \\
\hline Yes & $24(73 \%)$ & $71(71 \%)$ & $\chi^{2}=0.04$ \\
\hline Unknown & 1 & 2 & $\mathrm{p}=0.85$ \\
\hline
\end{tabular}

positive cases and the non-carriers. The data were collected by investigators without prior knowledge of CHEK2 status.

From each breast cancer patient, in the period between diagnosis and surgery, a detailed family cancer history was obtained, including data from first and second degree relatives, and a blood sample for DNA testing. There were no familial interrelationships (up to second degree relatives) between any of the patients included in this study.

The CHEK2*1100delC mutation was determined as described previously. ${ }^{8}$ All positive results were confirmed by sequence analysis. BRCA1/2 mutations were determined as also described previously, ${ }^{11}$ with slight modifications to include frequently mutated regions of BRCA2.

\section{Statistical analysis}

Baseline clinical-pathological characteristics and the family history of patients with a CHEK2*1100delC mutation were compared to those from non-carriers by using $\chi^{2}$ tests and, if applicable, $t$ tests. The clinical-pathological characteristics of the first breast cancer were analysed.

Events in patients with breast cancer and a germline CHEK2*1100delC mutation were compared to those in patients without the $C H E K 2^{*} 1100$ delC mutation by estimating Kaplan-Meier survival probabilities for disease-free survival, survival without contralateral breast cancer, distant metastasis-free survival, and overall survival for patients with breast cancer and a CHEK2*1100delC mutation as compared to patients without this mutation. The date of diagnosis of the first breast cancer was used as the moment of entry. Differences between the two groups were tested by using the log rank test. In the survival probability curves data were censored at 5 years of follow up.

Univariate Cox regression analysis was then performed for the following events: occurrence of contralateral tumours, local-regional recurrences, distant metastases, other malignancies, or death, or any combination of these events. To test the assumption of proportional hazards, a Cox proportional hazard model was performed in which an interaction term of CHEK2 status and a time dependent covariate was added. ${ }^{12}$ A significant effect of that interaction term denotes the presence of a time dependent effect and thus a violation of the proportional hazards assumption. Since age was one of the matching variables, a stratified Cox regression analysis was performed. Age was grouped into 10 year intervals and was used as a stratification variable. To explore the options for multivariate analysis, univariate Cox regression analyses were performed for each of the covariates from tables 1 and 2 (excluding age) for each event. p Values under 5\% were considered as statistically significant. All analyses were performed with SPSS version 11.01.

\section{RESULTS}

\section{Patient and tumour characteristics}

The germline CHEK2* 1100 delC mutation was found in 34 out of 1084 patients $(3.1 \%)$ with primary breast cancer. None of the patients with a $C H E K 2^{*} 1100$ delC mutation had a BRCAl or BRCA2 mutation. Patients with a CHEK2 mutation were significantly younger than patients without this mutation (49.0 $v 53.2$ years; $\mathrm{p}=0.03$ ).

When comparing patients with a CHEK2 mutation with the matched controls, a significant difference between the two groups was only found regarding steroid receptor status (table 1). In the patients with a germline CHEK2*1100delC mutation, $91 \%$ of the tumours were ER positive in contrast to $69 \%$ of the matched controls $(p=0.03)$, and $81 \%$ were PR positive compared to $53 \%$ of the matched controls $(p=0.04)$. No significant differences between the two groups were found with respect to tumour size, histological subtype, 
grade, or surgical procedure, or in choice of adjuvant systemic therapy and radiotherapy.

Table 2 shows the family histories of the patients in the study, stratified according to $C H E K 2^{*} 1100 d e l C$ carrier status. Mutation carriers more frequently had a first or second degree female relative with breast cancer $(p=0.03)$ or had any first or second degree relative with breast or ovarian cancer $(p=0.04)$. There were no apparent associations with cases who had first degree relatives with breast cancer at any age, first degree relatives with breast cancer at a younger age, or with cases who had ovarian cancer or male cancer in the family pedigree.

\section{Prognosis and survival}

In patients with and without the $C H E K 2^{*} 1100$ delC mutation, significant differences were observed regarding disease-free survival ( $\log$ rank 12.26; $\mathrm{p}=0.005)$, contralateral breast cancer-free survival (log rank 10.51; $\mathrm{p}=0.001)$, and distant metastasis-free survival ( $\log \operatorname{rank} 4.33 ; \mathrm{p}=0.04)$. No difference in overall survival has been observed as yet (log rank $0.38 ; \mathrm{p}=0.54)$. At 5 year follow up, $62 \%$ of the patients with a CHEK2*1100delC mutation showed an event in contrast to only $37 \%$ of the non-carriers (fig 1A): contralateral breast cancer had occurred in $26 \%$ (9\% in the noncarriers; fig $\mathrm{lB})$ and distant metastasis in $43 \%$ (28\% in the non-carriers; fig 1C). At the median follow up ( 3.8 years), an event had occurred in $56 \%$ of the carriers ( $8 \%$ in the noncarriers; fig 1A): contralateral breast cancer had occurred in $26 \%$ (4\% in the non-carriers; fig $1 \mathrm{~B})$ and distant metastasis in $29 \%$ ( $13 \%$ in the non-carriers; fig lC).

There was no violation of the assumption of proportional hazards regarding any event $(\mathrm{p}=0.596)$, contralateral breast cancer $(p=0.510)$, locoregional breast cancer $(p=0.992)$, distant metastasis $(\mathrm{p}=0.315)$, other malignancies $(\mathrm{p}=$ $0.553)$, or death $(p=0.529)$. The relative risks $(R R)$ and

\begin{tabular}{|c|c|c|c|}
\hline & $\begin{array}{l}\text { CHEK2 } \\
\text { mutation } \\
\text { present } \\
(\mathrm{n}=34)\end{array}$ & $\begin{array}{l}\text { CHEK2 } \\
\text { mutation } \\
\text { absent } \\
(n=102)\end{array}$ & Difference \\
\hline Any breast or ovarian cancer in & $19(56 \%)$ & $37(36 \%)$ & $\chi^{2}=4.05$ \\
\hline $\begin{array}{l}\text { first or second degree relative } \\
\text { Female breast cancer in } \\
\text { first degree relative }\end{array}$ & $7(21 \%)$ & $15(15 \%)$ & $\begin{array}{l}p=0.04 \\
\chi^{2}=0.65 \\
p=0.42\end{array}$ \\
\hline $\begin{array}{l}\text { Female breast cancer in first } \\
\text { or second degree relative } \\
\text { Number of female breast } \\
\text { cancer cases }\end{array}$ & $19(56 \%)$ & $35(34 \%)$ & $\begin{array}{l}\chi^{2}=4.96 \\
p=0.03\end{array}$ \\
\hline 0 & $15(44 \%)$ & $67(66 \%)$ & \\
\hline 1 & $13(38 \%)$ & $25(24 \%)$ & $\chi^{2}=5.02$ \\
\hline 2 or more & $6(18 \%)$ & $10(10 \%)$ & $\hat{p}=0.08$ \\
\hline $\begin{array}{l}\text { Female breast cancer in } \\
\text { first or second degree relative } \\
\text { under age } 60\end{array}$ & $9(26 \%)$ & $21(21 \%)$ & $\begin{array}{l}\chi^{2}=0.51 \\
p=0.47\end{array}$ \\
\hline $\begin{array}{l}\text { Female breast cancer in } \\
\text { first or second degree relative }\end{array}$ & $6(17 \%)$ & $16(15 \%)$ & $\begin{array}{l}\chi^{2}=0.07 \\
p=0.79\end{array}$ \\
\hline $\begin{array}{l}\text { under age } 50 \\
\text { Female breast cancer in } \\
\text { first or second degree relative } \\
\text { under age } 40\end{array}$ & $2(6 \%)$ & $9(9 \%)$ & $\begin{array}{l}\chi^{2}=0.30 \\
p=0.59\end{array}$ \\
\hline $\begin{array}{l}\text { Female breast cancer in } \\
\text { first or second degree relative } \\
\text { under age } 30\end{array}$ & $0(0 \%)$ & $3(3 \%)$ & $\begin{array}{l}\chi^{2}=1.02 \\
p=0.31\end{array}$ \\
\hline $\begin{array}{l}\text { Male breast cancer in first } \\
\text { or second degree relative }\end{array}$ & $0(0 \%)$ & $0(0 \%)$ & - \\
\hline $\begin{array}{l}\text { Ovary cancer in first or } \\
\text { second degree relative }\end{array}$ & $1(3 \%)$ & $5(5 \%)$ & $\begin{array}{l}\chi^{2}=0.23 \\
p=0.63\end{array}$ \\
\hline $\begin{array}{l}\text { Ovary and breast cancer in one } \\
\text { first or second degree relative }\end{array}$ & $0(0 \%)$ & $2(1.5 \%)$ & $\begin{array}{l}\chi^{2}=0.68 \\
p=0.41\end{array}$ \\
\hline
\end{tabular}

95\% confidence intervals $(95 \% \mathrm{CI})$ for patients with a CHEK2* 1100 delC mutation in comparison to non-carriers to develop a specific event are summarised in table 3. The highest relative risk ( $R R=5.74 ; 95 \%$ CI 1.67 to 19.65$)$ was found to be the development of contralateral breast cancer. Significant differences were also found with respect to the occurrence of distant metastasis ( $R R=2.81 ; 95 \%$ CI 1.20 to 6.58) and any of the mentioned events ( $R R=3.86$; $95 \%$ CI 1.91 to 7.78 ).

Because none of the covariates from tables 1 and 2 (excluding age) yielded any statistically significant contribution (results not presented) no multivariate analyses were performed.

\section{DISCUSSION}

In our series of breast cancer patients we found a prevalence of $3.1 \%$ of the $C H E K 2^{*} 1100$ delC mutation, which is somewhat higher than reported earlier. ${ }^{78}$ This may have been caused by one centre (the Rotterdam Cancer Centre) only including patients diagnosed before the age of 70 . Another explanation is that in our population the allele frequency of the CHEK2*1100delC mutation is higher. In both our study and that by Vahteristo et $a l^{7}$ the prevalence of the CHEK2* $^{*} 1$ 100delC mutation was higher in breast cancer patients with a family history of breast cancer $(3.9 \%$ and $3.1 \%$, respectively) than in patients without such a family history (2.4\% and $1.5 \%$, respectively). Among cases with a strong family history (derived from non-BRCAl/2 families self referred to family cancer clinics) the CHEK2*1100delC mutation is even more prevalent. ${ }^{7-9}$ Taken together, these facts suggest that the $C H E K 2^{*} 1100$ delC mutation is associated with a positive family history of breast cancer, unrelated to BRCA1/2 mutations. It has been suggested that the $C H E K 2^{*} 1100$ delC mutation acts together with an other as yet unidentified breast cancer susceptibility gene in these families. ${ }^{8} 9$

The patients in our study who carried the CHEK2*1100delC mutation more frequently developed steroid receptor positive tumours than did patients without this mutation. In this regard, these tumours appear more like $B R C A 2$ related tumours than BRCAl related tumours. Receptor positive tumours generally show a better prognosis than receptor negative tumours, ${ }^{13}$ but the $C H E K 2^{*} 1100$ delC positive patients in our study had a less favourable prognosis than non-carriers stratified for age and year of diagnosis, even though there were no significant differences in application of adjuvant systemic therapy. However, there is a marginal but statistically insignificant excess of lower grade cancer in the $C H E K 2^{*} 1100$ delC cases as compared to the nonCHEK2 $^{*} 1100$ delC cases $(70 \% \vee 59 \%)$. It therefore seems that the $C H E K 2^{*} 1100$ delC carriers represent a small but distinct group of breast cancer cases, like those carrying BRCA2 mutations but quite unlike those carrying BRCAl mutations in terms of histological grade and receptor status, and unlike the average sporadic breast cancer case in terms of prognosis. ${ }^{14-20}$

Whether this is due to loss of function of the CHEK2 protein in these cancers remains to be seen. The relationship between 1100delC carrier status and loss of heterozygosity at the gene locus is complex, but very few breast tumours from 1100delC carriers show CHEK2 protein expression. ${ }^{7}{ }^{9}$ Although the role of CHEK2 as an upstream activator of p53 following DNA damage has been controversial, there is some suggestion that its loss could impair DNA-damage induced apoptosis. $^{21}$

With respect to prognosis, the sixfold risk $(R R=5.98)$ in contralateral breast cancer in patients with a CHEK2*1100delC mutation compared to matched controls was most remarkable (table 3 ). This is almost twice as high 

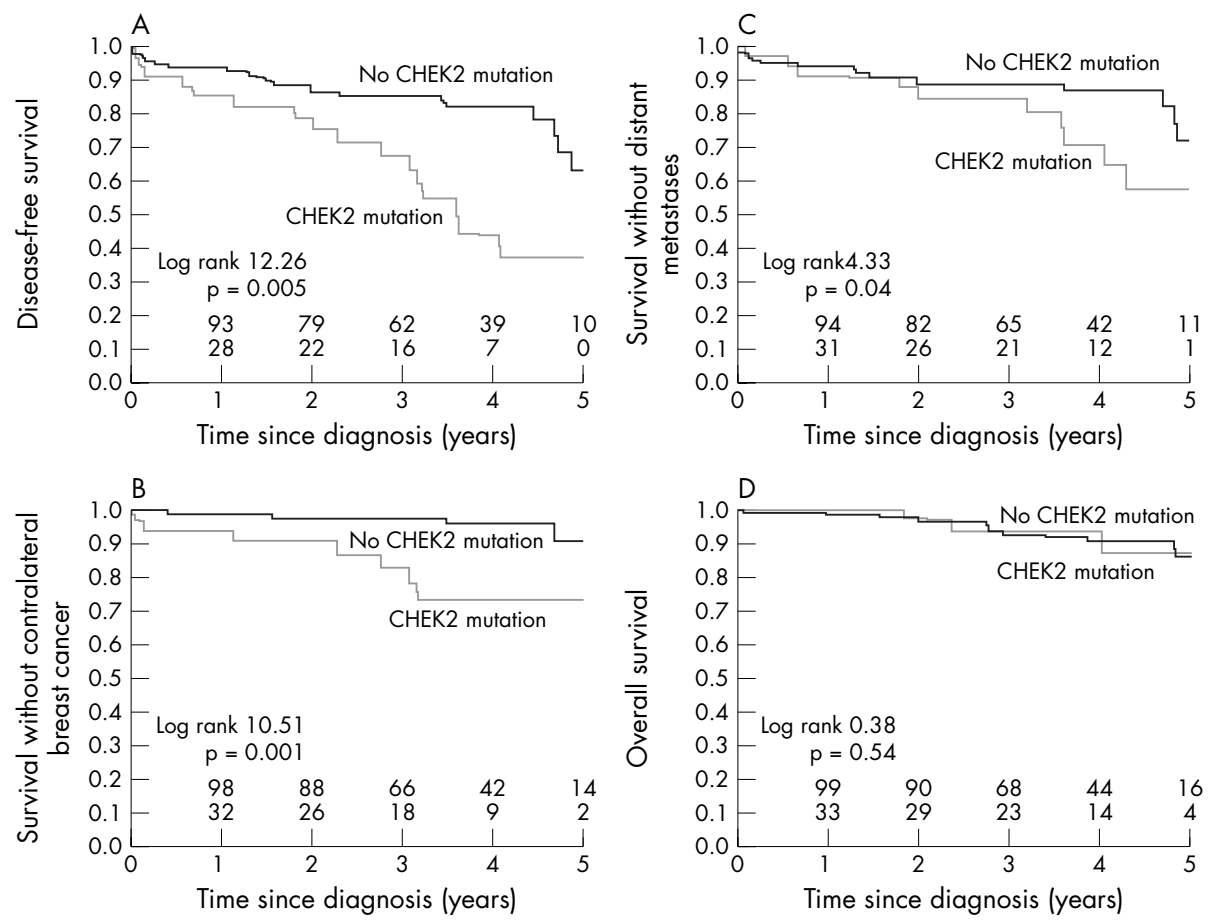

Figure 1 Probabilities of disease-free survival (A), survival without contralateral breast cancer (B), distant metastasis-free survival (C), and overall survival (D) for patients with breast cancer and the CHEK2*1100delC mutation $(n=34)$ compared to patients with breast cancer but without this mutation $(n=102)$.

as found for carriers of a BRCAl/2 mutation, ${ }^{14}{ }^{18}$ and difficult to reconcile with the only moderately elevated overall breast cancer risk conferred by this mutation. Yet our finding is supported by the studies of Vahteristo et $\mathrm{al}^{7}$ and Broeks et $a^{22}$ which also revealed a six times higher prevalence of $C H E K 2^{*} 1100$ delC carriers among patients with bilateral

Table 3 Events in patients with breast cancer and the CHEK2* 1100 delC mutation $(n=34)$ compared to those without this mutation $(n=102)$

\begin{tabular}{|c|c|c|c|c|}
\hline & $\begin{array}{l}\text { CHEK2 } \\
\text { mutation } \\
\text { present } \\
(n=34)\end{array}$ & $\begin{array}{l}\text { CHEK2 } \\
\text { mutation } \\
\text { absent } \\
(n=102)\end{array}$ & RR & $95 \% \mathrm{Cl}$ \\
\hline Any event & $16(47 \%)$ & $21(21 \%)$ & 3.86 & 1.91 to 7.78 \\
\hline $\begin{array}{l}\text { Contralateral } \\
\text { breast cancer* }\end{array}$ & $7(21 \%)$ & $4(4 \%)$ & 5.74 & 1.67 to 19.65 \\
\hline $\begin{array}{l}\text { Local-regional } \\
\text { recurrence† }\end{array}$ & $0(0 \%)$ & $5(5 \%)$ & 0.03 & 0.00 to 284 \\
\hline $\begin{array}{l}\text { Distant } \\
\text { metastasis }\end{array}$ & $10(29 \%)$ & $17(16 \%)$ & 2.81 & 1.20 to 6.58 \\
\hline $\begin{array}{l}\text { Other } \\
\text { malignancy } \ddagger\end{array}$ & $1(3 \%)$ & $1(1 \%)$ & 3.19 & 0.20 to 51.09 \\
\hline Death§ & $4(12 \%)$ & $9(9 \%)$ & 1.76 & 0.52 to 5.93 \\
\hline
\end{tabular}

Relative risks (RR) (univariate) and $95 \% \mathrm{Cl}$ are shown.

*One patient (without the CHEK2 mutation) had a local recurrence in addition to contralateral breast cancer. Two other patients (one patient with the CHEK2 mutation) had a later diagnosis of distant metastasis. tIncluding one case with ipsilateral second breast cancer.

tOther malignancies were: adenocarcinoma of the colon and

chondrosarcoma grade I (in patients with the CHEK2 mutation); and fibrous meningioma (in a patient without the CHEK2 mutation). Both patients with a CHEK2 mutation also had a contralateral breast cancer while the patient with the chondrosarcoma was later diagnosed with metastatic disease.

$\S$ All deaths were related to breast cancer and preceded by distant metastasis.

T Two of these were synchrone breast cancers (contralateral breast cancer within 1 week). as compared to unilateral breast cancer. However, we cannot exclude that $C H E K 2^{*} 1100$ delC carriers carry risk alleles at other, as yet unknown, breast cancer susceptibility genes. ${ }^{23}$

Another remarkable finding of our study is that $\mathrm{CHEK2}^{*} 1100 \mathrm{delC}$ mutation carriers are at higher risk for the development of distant metastasis $(\mathrm{RR}=2.81)$. This result suggests that $C H E K 2^{*} 1100 \mathrm{delC}$ associated tumours are more malignant relative to other breast tumours. However, thus far we have found no statistically significant effect of the CHEK2*1100delC variant on overall survival, although this may have been due to the short follow up. In fact, the survival curves tend to diverge at 5 years of follow up (fig ID).

Factors other than the $\mathrm{CHEK}^{*} 1100 \mathrm{delC}$ mutation might have caused the more malignant behaviour of tumours in carrier patients. Due to the small numbers, we were not able to analyse this in a multivariate model. A larger study should address the contribution of this CHEK2 variant to tumour characteristics and would also allow comparison of subgroups of patients, for example carrier versus non-carrier patients, both with metastases in follow up.

To our knowledge, this is the first report on the clinical behaviour of $C H E K 2^{*} 1100$ delC associated breast tumours in a consecutive series of unselected patients with breast cancer. Because the CHEK2*1100delC mutation seems to increase breast cancer risk only slightly with a mean earlier onset of 4 years, and because co-segregation with breast cancer in families where this variant occurs is not strong, ${ }^{7-9}$ DNA testing for this mutation has not yet been introduced into daily clinical management of breast cancer. In addition, very few breast cancers can be attributed to the CHEK2*1100delC mutation. As a result, we identified only a small number of carriers in our patient cohort, for which follow up was also relatively short. But if our findings of a more unfavourable prognosis for patients with $C H E K 2^{*} 1100 \mathrm{delC}$ related tumours are confirmed independently in other larger patient cohorts, CHEK2 status may become an important determinant when 
considering intensive surveillance and/or preventive measures, especially since the laboratory test can be carried out cost effectively if large numbers are tested.

\section{ACKNOWLEDGEMENTS}

We acknowledge the technical support of M Wasielewski, K KroeseJansema, CE Jacobi, and P Wijers-Koster, and MH Krijger-Weterman for her valuable help in collecting follow up data for the patients from the Leiden Medical Center. In addition, we thank the surgeons and mammacare nurse of The Diaconessenhuis Leiden, and the referring specialists in both academic cancer centres for their contribution, and the institutes for providing blood samples of healthy controls.

\section{Authors' affiliations}

G H de Bock, Department of Medical Decision Making, Leiden University Medical Center, Leiden, The Netherlands

M Schutte, C Seynaeve, J Blom, C T M Brekelmans, J G M Kliin, Department of Medical Oncology, Erasmus University Medical CenterDaniel den Hoed Cancer Center, Rotterdam, The Netherlands E M M Krol-Warmerdam, R A E M Tollenaar, Department of Surgery, Leiden University Medical Center, Leiden, The Netherlands

H Meijers-Heijboer, Department of Clinical Genetics, Erasmus University Medical Center, Rotterdam, The Netherlands

C J van Asperen, Department of Clinical Genetics, Leiden University Medical Center, Leiden, The Netherlands

C J Cornelisse, Department of Pathology, Leiden University Medical Center, Leiden, The Netherlands

P Devilee, Department of Human Genetics, Leiden University Medical Center, Leiden, The Netherlands

This study was supported by the Dutch Cancer Society (grant RUL 19971505).

Conflict of interest: none declared.

*Current address: Department of Epidemiology, Groningen University, Groningen, The Netherlands.

†The last two authors contributed equally, on behalf of the Leiden and Rotterdam groups, respectively.

\section{REFERENCES}

1 Collaborative Group on Hormonal Factors in Breast Cancer. Familial breast cancer: collaborative reanalysis of individual data from 52 epidemiological studies including 58,209 women with breast cancer and 101,986 women without the disease. Lancet 2001;358:1389-99.

2 Pharoah PD, Antoniou A, Bobrow M, Zimmern RL, Easton DF, Ponder BA. Polygenic susceptibility to breast cancer and implications for prevention. Nat Genet 2002;31:33-6

3 Cui J, Antoniou AC, Dite GS, Southey MC, Venter DJ, Easton DF, Giles GG, McCredie MR, Hopper JL. After BRCA1 and BRCA2 - what next? Multifactorial segregation analyses of three-generation, population-based Australian families affected by female breast cancer. Am J Hum Genet 2001;68:420-31.

4 Antoniou AC, Pharoah PD, McMullan G, Day NE, Stratton MR, Peto J, Ponder BJ, Easton DF. A comprehensive model for familial breast cancer incorporating BRCA1, BRCA2 and other genes. Br J Cancer 2002;86:76-83.

5 de Jong MM, Nolte IM, Te Meerman GJ, van der Graaf WT, Oosterwijk JC Kleibeuker JH, Schaapveld M, de Vries EG. Genes other than BRCA1 and BRCA2 involved in breast cancer susceptibility. J Med Genet 2002;39:225-42.

6 Goode EL, Dunning AM, Kuschel B, Healey CS, Day NE, Ponder BA, Easton DF, Pharoah PP. Effect of germ-line genetic variation on breast cancer survival in a population-based study. Cancer Res 2002;62:3052-7.

7 Vahteristo P, Bartkova J, Eerola H, Syrjakoski K, Ojala S, Kilpivaara O, Tamminen A, Kononen J, Aittomaki K, Heikkila P, Holli K, Blomqvist C,
Bartek J, Kallioniemi OP, Nevanlinna H. A CHEK2 genetic variant contributing to a substantial fraction of familial breast cancer. Am J Hum Genet 2002;71:432-8.

8 Meijers-Heijboer $\mathbf{H}$, van den Ouweland A, Kliin J, Wasielewski M, de Snoo A, Oldenburg R, Hollestelle A, Houben M, Crepin E, Veghel-Plandsoen M, Elstrodt F, van Duijn C, Bartels C, Meijers C, Schutte M, McGuffog L, Thompson D, Easton D, Sodha N, Seal S, Barfoot R, Mangion J, ChangClaude J, Eccles D, Eeles R, Evans DG, Houlston R, Murday V, Narod S, Peretz T, Peto J, Phelan C, Zhang HX, Szabo C, Devilee P, Goldgar D, Futreal PA, Nathanson KL, Weber B, Rahman N, Stratton MR. Low-penetrance susceptibility to breast cancer due to CHEK2(*)1 100delC in noncarriers of BRCA1 or BRCA2 mutations. Nat Genet 2002;31:55-9.

9 Oldenburg RA, Kroeze-Jansema K, Kraan J, Morreau H, Klijn JG Hoogerbrugge N, Ligtenberg MJ, van Asperen CJ, Vasen HF, Meijers C, Meijers-Heijboer H, de Bock GH, Cornelisse CJ, Devilee P. The CHEK2*1100delC variant acts as a breast cancer risk modifier in nonBRCA1/BRCA2 multiple-case families. Cancer Res 2003;63:8153-7.

10 Bartek J, Lukas J. Chk1 and Chk2 kinases in checkpoint control and cancer. Cancer Cell 2003;3:421-9.

11 de Bock GH, Tollenaar RA, Papelard H, Cornelisse CJ, Devilee P, van de Vijver MJ. Clinical and pathological features of BRCA1 associated carcinomas in a hospital-based sample of Dutch breast cancer patients. $\mathrm{Br} J$ Cancer $2001 ; 85: 1347-50$

12 Klein JP, Moeschberger ML. Survival analysis: techniques for censored and truncated data. 2nd ed. New York: Springer, 2003.

13 Chevallier B, Heintzmann F, Mosseri V, Dauce JP, Bastit P, Graic Y, Brunelle P, Basuyau JP, Comoz M, Asselain B. Prognostic value of estrogen and progesterone receptors in operable breast cancer. Results of a univariate and multivariate analysis. Cancer 1988;62:2517-24.

14 Verhoog LC, Brekelmans CT, Seynaeve C, van den Bosch LM, Dahmen G, van Geel AN, Tilanus-Linthorst MM, Bartels CC, Wagner A, van den Ouweland AM, Devilee P, Meijers-Heijboer EJ, Klijn JG. Survival and tumour characteristics of breast-cancer patients with germline mutations of BRCA1. Lancet 1998;351:316-21.

15 Lakhani SR, Jacquemier J, Sloane JP, Gusterson BA, Anderson TJ, van de Vijver MJ, Farid LM, Venter D, Antoniou A, Storfer-Isser A, Smyth E, Steel CM, Haites N, Scott RJ, Goldgar D, Neuhausen S, Daly PA, Ormiston W McManus R, Scherneck S, Ponder BAJ, Ford D, Peto J, Stoppa-Lyonnet D, Bignon Y-J, Struewing JP, Spurr NK, Bishop DT, Klijn JGM, Devilee P, Cornelisse CJ, Lasset C, Lenoir G, Barkardottir RB, Egilsson V, Hamann U, Chang-Claude J, Sobol H, Weber B, Stratton MR, Easton DF. Multifactorial analysis of differences between sporadic breast cancers and cancers involving BRCA1 and BRCA2 mutations. J Nat Cancer Inst 1998;90:1138-45.

16 Chappuis PO, Rosenblatt J, Foulkes WD. The influence of familial and hereditary factors on the prognosis of breast cancer. Ann Oncol 1999; 10:1163-70.

17 Phillips KA, Andrulis IL, Goodwin PJ. Breast carcinomas arising in carriers of mutations in BRCA1 or BRCA2: are they prognostically different? J Clin Oncol 1999;17:3653-63.

18 Verhoog LC, Berns EM, Brekelmans CT, Seynaeve C, Meijers-Heijboer EJ, Klijn JG. Prognostic significance of germline BRCA2 mutations in hereditary breast cancer patients. J Clin Oncol 2000;18:119S-24S.

19 Robson M. Are BRCA1- and BRCA2-associated breast cancers different? Prognosis of BRCA1-associated breast cancer. J Clin Oncol 2000;18:113S-8S.

20 Evans DG, Howell A. Are BRCA1- and BRCA2-related breast cancers associated with increased mortality? Breast Cancer Res 2004;6:E7.

21 Jack MT, Woo RA, Motoyama N, Takai H, Lee PW. DNA-PK and Chk2 synergistically activate a latent population of p53 upon DNA damage. J Biol Chem 2004; 279: 15269-73.

22 Broeks A, de Witte L, Nooijen A, Huseinovic A, Kliin JG, van Leeuwen FE, Russell NS, van't Veer $\sqcup$. Excess risk for contralateral breast cancer in CHEK2*1 100delC germline mutation carriers. Breast Cancer Res Treat 2004;83:91-3.

23 Meijers-Heijboer $\mathrm{H}$, Wiinen J, Vasen $\mathrm{H}$, Wasielewski M, Wagner $\mathrm{A}$ Hollestelle A, Elstrodt F, van den Bos R, de Snoo A, Fat GT, Brekelmans C, Jagmohan $S$, Franken $P$, Verkuijlen $P$, van den Ouweland $A$, Chapman $P$, Tops C, Moslein G, Burn J, Lynch H, Kliin J, Fodde R, Schutte M. The CHEK2 1100 delC mutation identifies families with a hereditary breast and colorectal cancer phenotype. Am J Hum Genet 2003;72:1308-14. 